Bryn Mawr College

Scholarship, Research, and Creative Work at Bryn Mawr College

Classical and Near Eastern Archaeology Faculty

Research and Scholarship

Classical and Near Eastern Archaeology

1995

\title{
Levels Taken on the Nike Bastion
}

Ira S. Mark

James C. Wright

Bryn Mawr College, jwright@brynmawr.edu

Let us know how access to this document benefits you.

Follow this and additional works at: http://repository.brynmawr.edu/arch_pubs

Part of the Classical Archaeology and Art History Commons, and the History of Art, Architecture, and Archaeology Commons

\section{Custom Citation}

Mark, Ira S., and James C. Wright. 1995. Levels Taken On The Nike Bastion. Hesperia 64:383-389.

This paper is posted at Scholarship, Research, and Creative Work at Bryn Mawr College. http://repository.brynmawr.edu/arch_pubs/53

For more information, please contact repository@brynmawr.edu. 


\section{LEVELS TAKEN ON THE NIKE BASTION}

7THE SCHOLARSHIP on the Akropolis of Athens is the most extensive, intricate, and potentially confusing of that for any site in Greece. This is owing partly to the intricacies of the site itself, whose stages extend from the Bronze Age through the Classical period to the Turkish occupation. Just as daunting, however, is a long and varied history of excavation. Much of the site was excavated in the 19th century, when scientific archaeology was in its infancy, and a good portion of more recent work has remained partly or wholly unpublished. My recent study of the Sanctuary of Athena Nike brought me face to face with these problems. $^{1}$ The encounter makes me all the more appreciative of how James Wright negotiates similar obstacles in his article on the Mycenaean entrance at the west side of the Akropolis, published in the 1994 volume of this journal. ${ }^{2}$

Wright and I have shared an interest in the Nike Bastion for many years and have talked back and forth on a number of points as work progressed. On one knotty problem we have long disagreed: the original height of the Mycenaean bastion. My study follows Iakovidis and Travlos in positing a gate wall northeast of the Mycenaean Nike Bastion; the original height of the bastion thus comes to $144.0 \mathrm{~m}$. or more above sea level. ${ }^{3}$

Wright does away with a gate wall and restores a freestanding tower at the west end of the bastion. His tower is of indeterminate height; the top of his bastion at the east comes to ca. +141.0 or $+141.5 \mathrm{~m}^{4}$

More important than this disagreement are other points, points for which there is more extant evidence, on which we agree. His reexamination of the remains beneath the Pinakotheke leaves me convinced that there was indeed a Mycenaean terrace on the site, ${ }^{5}$ while he concurs with me in seeing the upper stonework of the bastion as a post-Mycenaean repair. ${ }^{6}$

Anyone who reads Wright's study and mine carefully is bound to compare not only our conclusions but also our plans and drawings, and this calls for special comment. In 1979 Wright and William Dinsmoor, Jr., took an extensive set of levels on the bastion; these are recorded on three drawings that Wright publishes as figures 1, 3, and 5: section $b-b^{\prime}$. I regret that I first saw these drawings only in the finished publication: my researches on the bastion in 1982/83 and detailed study of archival drawings from the original excavation of the early bastion, many of which I published in 1993, cast doubt on these levels and, in some cases, show them to be in error. Although the differences are often considerable,

1 Mark 1993.

2 Wright 1994.

3 Iakovidis 1962, figs. 34, 35; Iakovidis 1983, plan 15; Travlos 1971, fig. 67; Mark 1993, p. 15.

4 Wright 1994, pp. 340-341, fig. 9.

5 See Mark 1993, p. 15, where I speak of a "line" of fortification to the north. Emend that now to a "terraced fortification".-

6 Mark 1993, pp. 15-17; Wright 1994, p. 340. 
over a quarter of a meter at some points, they do not greatly affect the interpretation of the Mycenaean remains of themselves. By contrast, a close reading of levels is essential to a proper understanding of the relation of the bastion walls to the earth stratum of the Stage II Nike Sanctuary, the stage that follows the Persian destruction. Although the level of the earth stratum can no longer be measured directly, it can be closely estimated from the level of the Stage III (mid 5th-century) sanctuary, which is founded directly upon it. The proper correlation of the preserved level of the bastion walls and Stage III is thus critical to the proper understanding of the 5th-century history of the cult site. It is important that I set the record straight.

The archival drawings that I referred to above were prepared during a comprehensive program of conservation and excavation on the Nike Bastion conducted from 1935 to 1939 by Nikolaos Balanos, then Director of the Restoration and Preservation of Akropolis Monuments. ${ }^{7}$

Alarmed at major settlement in the ashlar stonework of the bastion, Balanos dismantled the Nike Temple, the temple foundations, and almost all of the ashlar bastion. It was in the course of this work that the Mycenaean bastion first came to light and with it substantial remains from the pre-420's Nike cult. Important among the early cult finds is a small mid-5th-century predecessor of the Nike Temple, the so-called naïskos; a repository recut from the original base for the cult image; and an inscribed block from the Archaic altar. ${ }^{8}$ The foundations for the Nike Temple were too badly disintegrated to be used in the rebuilding of the site. Balanos replaced them with a massive concrete podium descending fully to bedrock, an installation that required the removal of the naïskos, the repository, and stretches of adjacent Mycenaean stonework. The early cult finds, reinstalled to place, and much of the Mycenaean bastion are currently accessible in an elaborate, multichambered crypt constructed beneath the ground level of the late 5th-century sanctuary. ${ }^{9}$

Before removing the pre-420's cult remains and at several points along the Mycenaean bastion, Balanos took levels; the archival plans give evidence of repeated sets of levels, in fact: some were relative to the northeast corner of the euthynteria of the Nike Temple, others were absolute, above sea level. One can document occasional errors in these readings, ${ }^{10}$ but to an overwhelming extent and to narrow tolerance they agree with one another, and in their agreement they validate the care with which Balanos conducted this aspect of his work. The archival drawings also punctiliously record the course heights of the Nike Temple steps and the ashlar bastion sheathing; at several points they indicate the level of the early remains relative to the steps and sheathing, and this gives an independent indication of level. Finally, one can check the drawings against excavation photographs of the early finds in situ.

7 Balanos 1956. The drawings are in the care of the Archaeological Society of Athens, and it is a pleasure to thank the Society for making them available to me for study and allowing the photography necessary to their publication.

8 Mark 1993, pp. 20-30, 32-34, 42-52.

9 For the limits of the crypt see Mark 1993, plan A.

10 There is one such error on the archival drawings that I reproduced: Mark 1993, p. 149, pl. 7. The absolute level on naïskos block F 3 is given as 140.643 . The correct figure is $c a .+140.55 \mathrm{~m} .=+140.92 \mathrm{~m}$. (the level of the naïskos euthynteria) -0.370 [E 3]/0.380[E 2] $\mathrm{m}$. (height of the euthynteria at the west). 
By all these sets of reference, the euthynteria of the naïskos lay at or very close to $1.295 \mathrm{~m}$. below the northeast corner of the Nike Temple euthynteria. A cross section of the early remains, the archival drawing that I reproduced as plate 11 , labels the distance as $1.295 \mathrm{~m}$. exactly, while a plan, my plate 7 , gives the level as $-1.305 \mathrm{~m} .{ }^{11}$ The same plan gives the absolute level of the northeast corner of the Nike Temple euthynteria as $+142.213 \mathrm{~m}$; two absolute levels are given for the euthynteria of the naïskos: $+140.916 \mathrm{~m}$. at the east end of block $\mathrm{E} 5$ and $+140.918 \mathrm{~m}$. toward the north end of E 3 . They come to $-1.297 \mathrm{~m}$. and $-1.295 \mathrm{~m}$., respectively, relative to the Nike Temple euthynteria. A less precise guide, but of interest as a check, is the correspondence between the level of the preserved north wall of the naïskos and the first step of the Nike Temple, evident in two archival cross sections, my plates 11 and 12, as well as in an excavation photograph of work in progress. ${ }^{12}$ Plate 11 gives the height of the first step of the Nike Temple as $0.255 \mathrm{~m}$. The naïskos north wall varies slightly in height from $1.547 \mathrm{~m}$. at the east to $1.582 \mathrm{~m}$. on block W $5 .^{13}$ If we take the mean, this gives a level for the naïskos euthynteria of $-1.31 \mathrm{~m}$. (=0.255 $-1.565 \mathrm{~m}$.) relative to the Nike Temple euthynteria. A third and final verification is given by the rough correspondence between the level of the naiiskos euthynteria and the third course of the bastion sheathing, as gauged from the cross section, my plate 11 , and from excavation photographs. ${ }^{14}$ Plate 11 gives the height of the combined Nike Temple euthynteria and bastion crown as $0.447 \mathrm{~m}$. and the heights of courses 1 and 2 of the sheathing as 0.446 and $0.445 \mathrm{~m}$., respectively. The negative sum from the upper edge of the euthynteria to the upper surface of course 3 is $-1.338 \mathrm{~m}$.

Anyone comparing my levels with Wright's has to contend, first, with the fact that we calculate from different absolute points of reference. My study follows Balanos in placing the northeast corner of the Nike Temple euthynteria at $+142.213 \mathrm{~m}$. Wright, who took levels with Dinsmoor and, as he states, prepared his study as a complement to the study published by Dinsmoor in 1980 on the predecessors of the Propylaia, ${ }^{15}$ follows Dinsmoor's absolutes. ${ }^{16}$ Dinsmoor's 1980 study gives the level of the northeast corner of the Nike Temple euthynteria as $+142.223 \mathrm{~m} .{ }^{17}$ The problems only start there, however. Dinsmoor (1980) records the level of the naïskos euthynteria as $+140.877 \mathrm{~m}^{18}$ In Wright's figure 3 , this number reappears (rounded off to $+140.88 \mathrm{~m}$.) as the level not of the naïskos euthynteria but of the cult-statue base/repository inside the naiskos. Wright informs me that he must have erred in placing the dot that locates this level, for his original notes follow Dinsmoor in placing the naïskos euthynteria at $+140.877 \mathrm{~m}$. The collar of the repository on the north, the side Wright indicates on his plan, is in fact considerably below the euthynteria, at or very

11 The archival drawings had to be greatly reduced in publication, and the figures are not always clearly legible. For their transcription see Mark 1993, Appendix B.

12 Balanos 1956, fig. 11.

13 Mark 1993, p. 46, fig. 7.

14 The two most important photographs are Welter 1939, fig. 2 (reproduced as Mark 1993, pl. 4) and Lemerle 1937, fig. 6 (Mark 1993, pl. 3:b).

15 Dinsmoor 1980; Wright 1994, p. 324, note 1.

16 The correlation is established by the level of the stylobate of the western gatehouse of the Propylaia at the west, entered on Dinsmoor's plan A as $+142.695 \mathrm{~m}$. (Dinsmoor 1980) and rounded off on Wright's figure 5: section $\mathrm{c}-\mathrm{c}^{\prime}$ to $+142.70 \mathrm{~m}$. (Wright 1994).

17 Dinsmoor 1980, plan A.

18 Dinsmoor 1980, plan A. 
near $+140.67 \mathrm{~m}$. The evidence comes, again, from Balanos' relative and absolute levels, from measurements on the archival drawings, and from excavation photographs. ${ }^{19}$

There are fewer points of reference for the preserved height of the Mycenaean bastion and the Stage I rebuilding of the crown. One has to be particularly wary of measuring at points where Balanos removed and replaced stonework. At one point, where the Mycenaean bastion crosswall runs beneath block $\mathrm{F} 1$ of the naïskos, Balanos rebuilt the rubble to a level $0.21 \mathrm{~m}$. above the original. F l, a block underpinning the south euthynteria of the naiskos, was originally seated on the crosswall, as made clear in a plan of the Nike Temple foundations, my plate 16, that was prepared before any of the Mycenaean stonework was removed. ${ }^{20}$ As rebuilt, the wall comes not to the resting edge of $F 1$ but nearly to the resting edge of the naïskos euthynteria.

The Stage I stonework along the western face of the bastion is another problem area. Here Balanos rebuilt part of the crown to a lower level than was originally uncovered. Wright reports a reading of $+140.77 \mathrm{~m}$. roughly midway on the west bastion face. ${ }^{21}$ A close indication of the pre-restoration height of the bastion at this point is given by an elevation, my plate 10 , and by an excavation photograph. ${ }^{22}$ Both make clear that the crown originally stood even with course 4 of the Nike Temple foundations. Plans of courses 3 and 4 of the Nike Temple foundations, my plates 16 and 17, show that course 3 sealed the Stage I crown beneath it. We can thus estimate the preserved height of the crown as $+140.42 \mathrm{~m} .{ }^{23}$ In $1983 \mathrm{I}$ took a level at a point over a meter to the north of Wright's reading, where the stonework appears not to have been removed: I got $+140.40 \mathrm{~m}$. Wright's figure is irreconcilable with this.

Balanos' levels and mine appear more consistent with Wright's along the south side of the bastion. For the southwest corner Wright gives $+139.12 \mathrm{~m} .{ }^{24}$ Balanos records three levels: $-3.06 \mathrm{~m}$. on my plate $7(+142.213-3.06=+139.15 \mathrm{~m}$.); $+139.171 \mathrm{~m}$. on $\mathrm{my}$ plate 8 ; and $+139.179 \mathrm{~m}$. on my plate 9 . At a point roughly $10.3 \mathrm{~m}$. from the southwest corner of the Mycenaean bastion, Wright's figures 1 and 5: section $b_{-}-b^{\prime}$ record a level of $+139.51 \mathrm{~m}$. Balanos' elevation of the south face of the bastion, my plate 9, gives the same point as $+139.558 \mathrm{~m}$. For the east end of the south side Wright's figures 1 and 5: section $b-b^{\prime}$ give $+141.00 \mathrm{~m}$. My 1983 measurement was $+140.67 \mathrm{~m}$., but I believe the difference is

19 It may be worthwhile to review these data to gauge Balanos' consistency. The plan, my plate 7, records the northern collar at $+140.673 \mathrm{~m}$. The same plan enters the relative level $-1.64 \mathrm{~m}$. on the floor of the upper cavity of the repository inside the collar. As measured on the stone, the upper cavity is cut down $0.095 \mathrm{~m}$. from the collar on the north (Mark 1993, p. 20). The northern collar is thus at $-1.545 \mathrm{~m}$., or in absolute elevation, $+140.67 \mathrm{~m}$. One can check this against the position of the repository relative to the naïskos euthynteria. As entered on the cross section, my plate 12, the distance from the upper edge of the naïskos euthynteria to the northern collar was $0.24 \mathrm{~m}$.; compare the excavation photographs Balanos 1956, figs. 12, 13. Taking $+140.92 \mathrm{~m}$. as the absolute level of the naïskos euthynteria (converted from the relative level $-1.295 \mathrm{~m}$.), this gives $+140.68 \mathrm{~m}$. for the collar.

${ }^{20}$ Compare Mark 1993, pl. 7; as explicated (p. 150), the plan appears to show the crosswall after the removal of over a meter of its height.

${ }^{21}$ Wright 1994, figs. 1 and 3.

22 Balanos 1956, fig. 17.

${ }^{23}$ At the west, the Nike Temple foundations and the bastion sheathing are bonded and have the same course heights. Courses 1,2 , and 3 of the sheathing are respectively $0.446,0.445$, and $0.456 \mathrm{~m}$. in height. The combined temple euthynteria and bastion crown is $0.447 \mathrm{~m}$. high (see Mark 1993, p. 151, pl. 11): +142.213 $-0.447-0.446-0.445-0.456=+140.419$.

${ }^{24}$ Wright 1994, figs. 1 and 3. 
more apparent than real. I measured on a boulder $c a .16 \mathrm{~m}$. from the southwest corner of the Mycenaean bastion. ${ }^{25}$ As gauged from Wright's figure 1, his reading of $+141.00 \mathrm{~m}$. was taken farther out than mine, about seventeen meters from the southwest corner of the bastion, roughly a meter from the eastern wall of the crypt.

Two levels that Wright records in the vicinity of the Stage III rectangular altar require comment: $+140.79 \mathrm{~m}$. west of the altar and $+140.86 \mathrm{~m}$. to the east. ${ }^{26}$

Wright does not discuss these levels in his text, but I want to make it clear that they do not measure the preserved height of the Mycenaean bastion as uncovered by the excavators. ${ }^{27}$ Balanos cut into the ancient fill to provide adequate headroom in the modern crypt: these are thus levels of the modern floor and have no ancient significance. Moreover, the readings appear inappropriate for the floor. I did not measure the level of the crypt floor, but the Stage III rectangular altar gives a point of reference. Balanos states that the altar is set $0.10 \mathrm{~m}$. above the level of the naïskos euthynteria. ${ }^{28}$ Taking the naïskos euthynteria as $+140.92 \mathrm{~m}$. gives an elevation of $+141.02 \mathrm{~m}$. for the altar bed. This accords closely with the level of the base slab for the altar given on my plate 11 , that is, $-1.195 \mathrm{~m}$. relative to the Nike Temple euthynteria $(+142.213-1.195=+141.018 \mathrm{~m}$.). The base slab is a maximum of $0.37 \mathrm{~m}$. high; ${ }^{29}$ it is thus bedded at $c a .+140.65 \mathrm{~m}$. And to compensate for the lowered level of the modern crypt, the slab is in turn seated on a high, modern concrete podium. ${ }^{30}$ My photograph of the inner face of the bastion on the north, plate $6: \mathrm{b}$, includes a measuring rod and allows a better gauge: the crypt floor is in the vicinity of $+139.75 \mathrm{~m}$. Note finally that the point Wright indicates for the level east of the rectangular altar is outside the limits of the modern crypt.

Having pored for years over Balanos' plans I have come to recognize his strong suit. He had little interest in pottery and stratigraphy, but when civil engineering was at issue, he came to life. He loved plans, cross sections, levels, and well-cut ashlar masonry. This review of the evidence substantiates the overwhelming reliability of his levels. I followed them closely in my study, checking them exhaustively against each other and, wherever possible, against the extant evidence. They need to form the starting point of any future work on the site.

\section{APPENDIX}

To clarify the findings of this note, I have compiled a table that contrasts Balanos' levels and mine with Dinsmoor's (Dinsmoor 1980, plan A) and those taken jointly by Dinsmoor and Wright. All Balanos' levels have been converted to absolute elevations (northeast corner of the Nike Temple euthynteria $=+142.213 \mathrm{~m}$.) and rounded off to the nearest centimeter.

\footnotetext{
25 Mark 1993, plan A.

26 Wright 1994, fig. 3. For the Stage III rectangular altar see Mark 1993, pp. 53-54. the Stage I crown) stood to $c a$. $+140.10 \mathrm{~m}$. (Mark 1993, pp. 15-16).

28 Balanos 1956, p. 787.

29 Mark 1993, p. 53.

30 Mark 1993, pl. 5 shows this concrete podium at lower left and right.
}

27 The best extant gauge of that height is the original level of the Mycenaean crosswall and the preserved level of the Mycenaean bastion on the north. Balanos gives the level of the crosswall inside the north euthynteria of the naïskos as +140.545 m. (Mark 1993, p. 149, pl. 7). It was slightly lower inside the south euthynteria, as established by the resting surface of F 1: ca. $+140.33 \mathrm{~m}$. On the north, the Mycenaean bastion (as opposed to 
Dinsmoor's 1980 levels and the Dinsmoor-Wright levels have been adjusted to Balanos' absolute by subtracting $0.010 \mathrm{~m}$., and Dinsmoor's levels have been rounded to the nearest centimeter. (B) denotes that a level is according to Balanos; (M), Mark; (D), Dinsmoor 1980; and (D-W), Dinsmoor-Wright. All measurements are in meters.

\section{LEVELS TAKEN ON THE NIKE BASTION}

\begin{tabular}{|l|l|l|l|}
\hline Place of measurement & Level $(\mathrm{B}, \mathrm{M})$ & $\mathrm{D}, \mathrm{D}-\mathrm{W}$ & Difference \\
\hline $\begin{array}{l}\text { Naïskos } \\
\text { euthynteria }\end{array}$ & $+140.91 / .92(\mathrm{~B})$ & $+140.87(\mathrm{D})$ & $-0.04 / .05$ \\
\hline $\begin{array}{l}\text { Western crown of } \\
\text { bastion }\end{array}$ & $\begin{array}{l}c a .+140.42(\mathrm{~B}) \\
+140.40(\mathrm{M})\end{array}$ & $+140.76(\mathrm{D}-\mathrm{W})$ & $\begin{array}{l}c a .+0.34(\mathrm{D}-\mathrm{W} / \mathrm{B}) \\
+0.36(\mathrm{D}-\mathrm{W} / \mathrm{M})^{31}\end{array}$ \\
\hline $\begin{array}{l}\text { Southwest corner } \\
\text { of bastion }\end{array}$ & $+139.15 / .17 / .18(\mathrm{~B})$ & $+139.11(\mathrm{D}-\mathrm{W})$ & $-0.04 / .06 / .07$ \\
\hline $\begin{array}{l}\text { Southern bastion } \\
\text { ca. } 10.3 \text { m. from } \\
\text { southwest corner }\end{array}$ & $+139.56(\mathrm{~B})$ & $+139.50(\mathrm{D}-\mathrm{W})$ & -0.06 \\
\hline $\begin{array}{l}\text { Southern bastion, } \\
\text { east end }\end{array}$ & $+140.67(\mathrm{M})$ & $+140.99(\mathrm{D}-\mathrm{W})$ & $+0.32^{32}$ \\
\hline $\begin{array}{l}\text { Floor of the } \\
\text { modern crypt } \\
\text { near the Stage III } \\
\text { rectangular altar }\end{array}$ & Est. $+139.75(\mathrm{M})$ & $+140.78 / .85(\mathrm{D}-\mathrm{W})$ & Est. $+1.03 / .10$ \\
\hline
\end{tabular}

\section{BIBLIOGRAPHY}

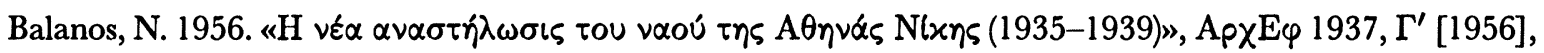
pp. 776-807

Dinsmoor, W. B., Jr. 1980. The Propylaia to the Athenian Akropolis, I, The Predecessors, Princeton

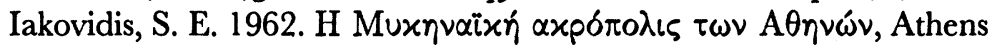

- 1983. Late Helladic Citadels on Mainland Greece (Monumenta graeca et romana 4), Leiden

Lemerle, P. 1937. "Chronique des fouilles et découvertes archéologiques en Grèce en 1937," $B C H 61$, pp. $441-476$

Mark, I. S. 1993. The Sanctuary of Athena Nike in Athens: Architectural Stages and Chronology (AIA Monograph New Series 2 and Hesperia Supplement 26), Princeton

Welter, G. 1939. "Vom Nikepyrgos," $A A$ [7dI 54], cols. 1-22

Wright, J. C. 1994. "The Mycenaean Entrance System at the West End of the Akropolis of Athens," Hesperia 63, pp. 323-360

Center for Advanced Study in the Visual Arts

IRA S. MARK

National Gallery of Art

Washington, DC 20565

31 The (M) and (D-W) levels are at different points along the west face of the bastion: (D-W) ca. $4.75 \mathrm{~m}$., (M) $c a .6 .0 \mathrm{~m}$. from the southwest corner.

32 The (M) and (D-W) levels appear to be taken at different points: (M) ca. $16.0 \mathrm{~m}$., (D-W) ca. $17.0 \mathrm{~m}$. from the southwest corner of the bastion. 


\section{NOTE}

Both William Dinsmoor, Jr., and I set out to make an accurate record of the pertinent elevations of the area of the west entrance to the Akropolis. That is the point of my figure 1 (Wright 1994). Aside from the unfortunate mistake in my figure 3, all the elevations resulted from our on-site survey. It is to me little wonder that there are discrepancies since the conditions for working under the Bastion are exceptionally difficult using conventional surveying equipment, and as Mark's study makes clear, the area is a minefield for any scholar who did not have access to Balanos' records.

Regarding Mark's elevation of +140.67 for the east end of the south side and the one I published of +141.00 , I can offer no explanation for the discrepancy since Dinsmoor had extensive notes that he had compiled over many years of work and which he consulted for making his plans. Without consulting Dinsmoor's archives, it is impossible to know where Dinsmoor took this reading.

The two levels I published that lie in the vicinity of Mark's Stage III rectangular altar $(+140.79$ and +140.86$)$ are indeed levels of the modern floor. Dinsmoor himself published the first elevation (as "GRADE 140.786" on Plan A 1980, Dinsmoor). Short of measuring the point today, the issue in my view remains moot.

I offer the following table, which includes the elevations taken by Dinsmoor and myself in 1979 and those used by Dinsmoor in his 1980 publication. In this manner it is possible to reconcile Dinsmoor's readings with those of Balanos and Mark with the result that the areas of disagreement are substantially reduced.

\begin{tabular}{|l|l|l|l|l|}
\hline $\begin{array}{l}\text { Place of } \\
\text { Measurement }\end{array}$ & Level (B), (M) & Difference & Reconciled \\
\hline $\begin{array}{l}\text { Northeast euthynteria } \\
\text { Nike Temple }\end{array}$ & $+142.213(\mathrm{~B})$ & $\begin{array}{l}+142.223(\mathrm{D} 1980) \\
+142.177(\mathrm{DW})\end{array}$ & $\begin{array}{l}+0.01 \\
+0.036\end{array}$ & \\
\hline Naïskos euthynteria & $+140.91 / .92(\mathrm{~B})$ & $+140.872(\mathrm{DW})$ & & +140.908 \\
\hline $\begin{array}{l}\text { North collar of cult } \\
\text { statue base/repository }\end{array}$ & $+140.67 / .68(\mathrm{~B})$ & $\begin{array}{l}+140.632(\mathrm{DW}) \\
\text { Wright Fig. } 3 \text { in error }\end{array}$ & & +140.668 \\
\hline $\begin{array}{l}\text { Western crown of } \\
\text { bastion }\end{array}$ & $\begin{array}{c}c a .+140.42(\mathrm{~B}) \\
+140.40(\mathrm{M})\end{array}$ & {$[+140.77](\mathrm{D})$} & & {$[+140.78]$} \\
\hline $\begin{array}{l}\text { Southwest corner } \\
\text { of bastion }\end{array}$ & $+139.15 / .17 / .18(\mathrm{~B})$ & $+139.117(\mathrm{DW})$ & & +139.153 \\
\hline $\begin{array}{l}\text { Southern bastion, } \\
\text { east end }\end{array}$ & $+140.67(\mathrm{M})$ & {$[+140.718](\mathrm{D})$} & & {$[+140.754]$} \\
\hline
\end{tabular}

$B=$ Balanos $\quad M=$ Mark $\quad$ DW $=$ Dinsmoor - Wright

[ ] place of measurement uncertain

Bryn Mawr Gollege

James C. WRight

Department of Classical and

Near Eastern Archaeology

Bryn Mawr, Pa 19010-2899 